\title{
Effect of Harvesting Time and Iron Application on Moldavian balm
}

\author{
Prshang KHALILI*, Reza AMIRNIA
}

\author{
Faculty of Agriculture,Urmia University,Iran;Pkhalili95@yahoo.com ("corresponding author); ramirnia@gmail.com
}

\begin{abstract}
Dracocephalum moldavica L. of the Labiatae family is an annual herbaceous plant. In Iran it is known as Badrashbi and Badrashboo. Recent publications have reported antibacterial and antimicrobial properties of its essential oil, which have a wide usage in industry. In this research, the effects of iron foliar application and different yields' harvest times on the essential oil content and some morphological treats (plant height, branch number, fresh and dry weights, essential oil content and leaf Iron content) were investigated under experimental study in faculty of Agriculture of Urmia University during 2012. A factorial experiment in a randomized complete block design with three replications was used in the present study. Results showed that foliar application of iron had a significant effect on branch number, fresh and dry weight, biomass and oil percentage. Similarly, harvest time had a significant influence on fresh and dry weight, essential oil content, essential oil yield and leaf iron content, but its effect was not significant on stem diameter and branch number. The best harvest time for Dracocephalum moldavica L. was at $100 \%$ of flowering and $6 \mathrm{ml} / \mathrm{l}$ of iron application showed the best results in all characters measured.

Keywords: biomass, Dracocephalum moldavica L., essential oil, flowering stage, micro nutrient, oil yield
\end{abstract}

\section{Introduction}

Moldavian balm (Dracocephalum moldavica L.) of the Labiatae family is an annual herbaceous plant. It is an annual plant native to central Asia and naturalized in eastern and central Europe (Dastmalchi et al., 2007a). Several classes of secondary metabolites have been isolated from aerial parts of Dracocephalum modavica L., these including essential oil (Venskutonis et al., 1995), polar compounds such as hydroxycinnamic acids and flavonoids, with caffeic and ferulic acids, luteolin-7-O-glucoside, rosmarinic acid, luteolin and apigenin.

The use of essential oils is important not only in preservation of food, but also in control of human and plant diseases of microbial origins (Baratta et al., 1998). Anti-viral and anti-bacterial properties of this plant are related to neral and geranial components. Recent pharmacological studies have confirmed some medicinal properties of Moldavian balm including antioxidant effect (Dastmalchi et al., 2007b) and prevention of injuries such as heart infarct size (Najafi et al., 2007). The essential oils of Moldavian balm have been investigated previously in Hungary, Iran, Magnolia and Finland (Galambosi et al., 2002).

Plant yield and essential oil composition are affected by many factors including harvest times, agronomy practice (Marotti et al., 1993), different water regimes (Safikhani et al., 2007), nutrients (Rahbarian et al., 2009), genetic, ecologic and climatic conditions. Nutrients and harvest time have a great share on yields and photochemical composition of plants (Heidari et al., 2011). Among nutrients, microelements play an important role in production and productivity (Hopkins and Huner, 2004). There is little information on the response of this crop to applied nutrients, particularly of micronutrients (Zehtab-Salmasi et al., 2012). Iron $(\mathrm{Fe})$ is a cofactor for approximately 140 enzymes that catalyze unique biochemical reactions (Brittenham, 1994). The alkaline nature of most Iranian soil predisposes to Fe deficiency, so that plants usually suffer from short supply of this nutrient (Khoshgoftarmanesh, 1386). It has been reported that iron foliar application increased the peanut yield (Singh and Dayal, 1992), safflower seed yield and seeds per head (Zareie et al., 2011) in alkaline soils. The aim of the present study was to investigate the effects of different concentrations of iron chelate fertilizer and harvest times of Dracocephalum moldavica L. on several yield and quality factors, as well as the content of essential oils obtained from this plant.

\section{Materials and methods}

This research was conducted in research field of Agronomy Faculty of Urmia University (Iran) located on Nazlou campus complex, in 2012. The study area was situated in latitude $37^{\circ} 32^{\prime} \mathrm{N}$ and longitude $45^{\circ} 2^{\prime} \mathrm{E}, 1320 \mathrm{~m}$ above sea level, with $365.5 \mathrm{~mm}$ annual rainfall rate. Soil texture of experimental site was clay loam, alkaline $(\mathrm{pH}=8.2)$ with electrical conductivity (EC) of $0.54 \mathrm{ds} / \mathrm{m}$. Experimental treatments were arranged as factorial based experiment in a randomized complete block design with three replications. The first factor was referring to four levels of iron application $(0,2,4$ and $6 \mathrm{ml} / \mathrm{l})$, while the second factor was four physiological based harvest times (10, 25, 50 and 100\% of flowering stage).

To prepare field soil, moldboards plow tillage was carried out in 2011 autumn and after favorable climate conditions 
506

in the spring of 2012, secondary tillage operations for the final seed bed preparation were done by cultivator concomitant with adding $70 \mathrm{~kg} / \mathrm{ha}$ nitrogen manure. Plots were 9 meter square and within each plot, furrows were created as distance between planting rows and two plants (within rows) were 50 and 20 centimeter, respectively. In order to prevent any negative effect of herbicides, hand weeding was used for weeds control. Irrigation regimes were adjusted based on weather conditions and plant phonological stages during the growing season. Iron foliar application was done after afternoon irrigation before flowering stage.

Fresh and dry weights of plants were determined by digital weighing scales. Shade dried material was used for water distillation using a Clevenger apparatus for $4 \mathrm{~h}$. The data were subjected to analysis of variance using SAS program for a completely randomized design and significant differences were determined using Duncan's Multiple Range Test (DMRT) at 0.05 probability.

\section{Results and discussion}

\section{Plant height}

Analysis of variance showed significant differences $(\mathrm{p}<0.05)$ in plant height among treatments (Tabs. 1,2). The maximum plant height $(52 \mathrm{~cm})$ was recorded in plants treated with iron $(6 \mathrm{ml} / \mathrm{l})$ and the minimum $(45 \mathrm{~cm})$ was found with control (Fig. 1). The highest plant height $(58 \mathrm{~cm})$ was recorded in plants harvested at $100 \%$ flowering time (Fig. 2). The highest plants were observed for individuals treated with $6 \mathrm{ml} / \mathrm{l} \mathrm{Fe}$, this not being particularly surprising, since $\mathrm{Fe}$ is a key component of numerous biochemical enzymes and molecules, such as chlorophyll (Hopkins and Huner, 2004). This result is consistent with the findings of Pol et al. (2003), which showed a positive effect of foliar application of some micronutrients including Fe on Withania somnifera L. (also known as Ashwagandha).

\section{Branch numbers}

Analysis of variance showed significant differences $(p<0.05)$ in branch numbers (per plant) among treatments. Maximum (10.5) and minimum (9) branches was observed in iron $(6 \mathrm{ml} / \mathrm{l})$ treated plants and control respectively. Harvest time had no significant effect on number of branch. Similar result was reported with foliar application of $\mathrm{Fe}$ and Zn on Coriandrum sativum L. at vegetative, flowering and fruit reach stages (Maurya, 1990).

\section{Fresh and dry weight}

Fresh and dry weight of upper parts of Moldavian balm significantly changed by different iron application and harvest time. By way of comparison, the maximum fresh (34 g per plant) and dry weight (10 g per plant) of upper parts of plants were obtained from plants treated with $6 \mathrm{ml} / \mathrm{l}$ iron, while minimum fresh (18 g per plant) and dry weight $(7.3 \mathrm{~g}$ per plant) was obtained from control (Tab. 1); also, harvest time at the phase of $100 \%$ flowering had the highest fresh and dry weight (Tab. 2). Zehtab-Salmasi et al., 2008, reported that foliar application of $\mathrm{Fe}, \mathrm{Zn}$ and $\mathrm{B}$ cause an increase of fresh and dry weight, leaf area and oil percentage of treated plants of Mentha piperita L. compared with control. The increase in yield after foliar application of $\mathrm{Fe}$ could be attributed to the direct absorption of the element by the foliage sprayed solution. This may be attributed to relatively less availability of soil applied Fe to plants, because of its conversion to un-available forms (Takkar and Nayyar, 1979). Said AL-Ahi (2010) in Fe and Zn foliar application on Ocimum basilicum L., in both salt stress and without salt stress, reported that the maximum amount of dry weight was obtained when both iron and zinc were used in whiteout salt stress condition. Photosynthetic production transfers during flowering stage through the root and other upper parts of plant reduces, respectively flowers will grow in size and therefore plant biomass increases.

Tab. 1. Effect of foliar application of Fe on several characters of Dracocephalum moldavica $\mathrm{L}$.

\begin{tabular}{|c|c|c|c|c|c|c|}
\hline $\begin{array}{l}\text { Treatments (iron foliar } \\
\text { application) }\end{array}$ & $\begin{array}{l}\text { Plant height } \\
\quad(\mathrm{cm})\end{array}$ & $\begin{array}{c}\text { Fresh weight of upper } \\
\text { parts }(\mathrm{g})\end{array}$ & $\begin{array}{l}\text { Dry weight of upper } \\
\text { parts }(\mathrm{g})\end{array}$ & Essential Oil\%(m/v) & Oil yield $\left(\mathrm{g} / \mathrm{m}^{2}\right)$ & Fe-content(mg) \\
\hline Control & $45 b$ & $18 \mathrm{c}$ & $7 b$ & $0.67 c$ & $6.51 \mathrm{~b}$ & $3.3 c$ \\
\hline $2 \mathrm{ml} / \mathrm{l}$ & $48 \mathrm{ab}$ & $21 c$ & $8 b$ & $0.75 b c$ & $6.62 b$ & $3.8 \mathrm{c}$ \\
\hline $4 \mathrm{ml} / 1$ & $51 \mathrm{a}$ & $27.4 \mathrm{~b}$ & $9 \mathrm{a}$ & $0.9 \mathrm{a}$ & $6.79 \mathrm{~b}$ & $4.25 b$ \\
\hline $6 \mathrm{ml} / \mathrm{l}$ & $53 a$ & $34 a$ & $10 \mathrm{a}$ & $0.8 \mathrm{ab}$ & $7.24 \mathrm{a}$ & $5.1 \mathrm{a}$ \\
\hline
\end{tabular}

Tab. 2. Effect of harvest time on several characters of Dracocephalum moldavica $\mathrm{L}$.

\begin{tabular}{|c|c|c|c|c|c|c|}
\hline Harvesting stages & $\begin{array}{c}\text { Plant height } \\
(\mathrm{cm})\end{array}$ & $\begin{array}{l}\text { Fresh weight of } \\
\text { upper parts(g) }\end{array}$ & $\begin{array}{c}\text { Dry weight of upper } \\
\text { parts }(\mathrm{g})\end{array}$ & $\begin{array}{c}\text { Essential } \\
\text { Oil\%(m/v) }\end{array}$ & Oil yield $\left(\mathrm{g} / \mathrm{m}^{2}\right)$ & Fe-content $(\mathrm{mg})$ \\
\hline $10 \%$ of flowering & $39.5 c$ & $20.3 b$ & $7.5 b$ & $0.62 c$ & $6.2 \mathrm{c}$ & $3.9 \mathrm{~b}$ \\
\hline $25 \%$ of flowering & $48.4 b$ & $22.25 b$ & $8 b$ & $0.7 \mathrm{c}$ & $6.8 \mathrm{~b}$ & $3.9 b$ \\
\hline $50 \%$ of flowering & $52.1 \mathrm{~b}$ & $30 \mathrm{a}$ & $9.4 \mathrm{a}$ & $0.97 \mathrm{a}$ & $6.9 \mathrm{ab}$ & $4.4 \mathrm{a}$ \\
\hline $100 \%$ of flowering & $57.3 a$ & $30 \mathrm{a}$ & $10 \mathrm{a}$ & $0.85 b$ & $7.3 \mathrm{a}$ & $4.2 \mathrm{ab}$ \\
\hline
\end{tabular}




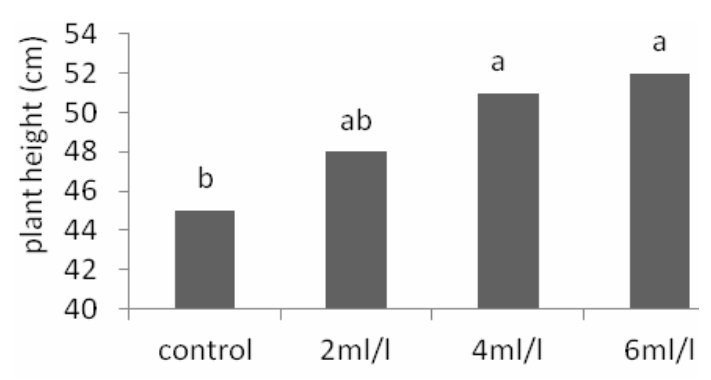

Fig.1. Effect of iron application on plant height

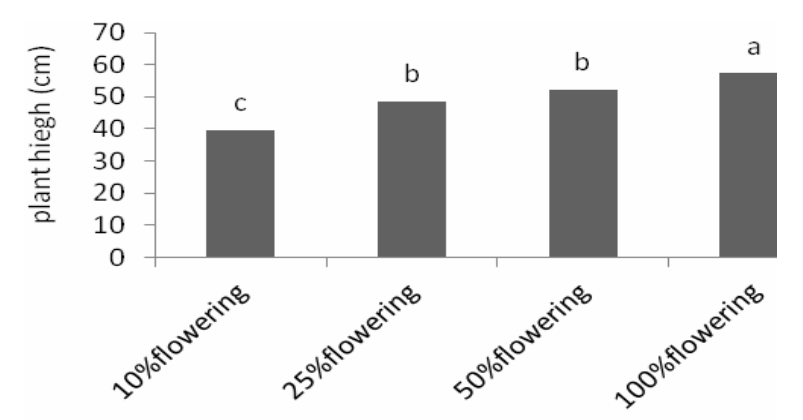

Fig.2. Effect of harvest time on plant height

\section{Essential oil content}

The effect of iron application and harvest time on essential oil content of $D$. moldavica $\mathrm{L}$. were significant at $\mathrm{p}<0.05$. The essential oil content was the highest $(0.9 \%$ $\mathrm{m} / \mathrm{v}$ ) in plants treated with $4 \mathrm{ml} / \mathrm{l}$ iron (Tab. 1). Harvest of plants at $50 \%$ of flowering could produce greater quantities of essential oil compared with 10,25 and $100 \%$ of flowering, while the lowest essential oil content was obtained from plants harvested at $10 \%$ of flowering with $0.62 \% \mathrm{~m} / \mathrm{v}$, respectively (Tab. 2). Harvesting at different moments dependent of the flowering stage of the plants showed a significant effect on the essential oil accumulation in upper parts of plants. The established maximum values may help in technology development, if checked its interactions with genotype, vegetation stage and weather conditions. Increase of essential oil with utilization of $\mathrm{Fe}$ and $\mathrm{Zn}$ has been reported by other researcher in Coriandrum sativum L. (Maurya, 1990) and Mentha arvensis L. (Pande et al., 2007). The number of glands that respires oil in the plant is not fix and by favoring the leaf growth by iron application, it may cause a more significant growth of oil content (Hopkins and Huner, 2004).

\section{Essential oilyield}

Essential oil yield was significantly affected by foliar application and harvest time at $\mathrm{p}<0.05$ (Tabs. 1, 2). Mean comparison cleared that essential oil yield in D. moldavica $\mathrm{L}$. plants treated with $6 \mathrm{ml} / \mathrm{l}$ iron was higher than other treatments and control (Fig. 3). On the same basis, it was proven that plants harvested at $100 \%$ of flowering produced the highest essential oil yield $\left(7.3 \mathrm{~g} / \mathrm{m}^{2}\right)$ and those harvested at $10 \%$ of flowering had the lowest content $\left(6.2 \mathrm{~g} / \mathrm{m}^{2}\right)$ (Fig. 4). Results show that foliar application of iron had a positive effect in treated range on essential oil yield, being in agreement with previous works (ZafarHaider et al., 2011).

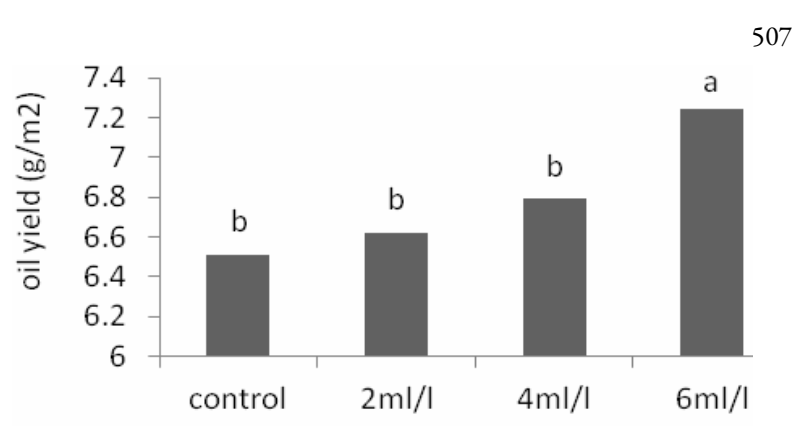

Fig.3. Effect foliar application on oil yield

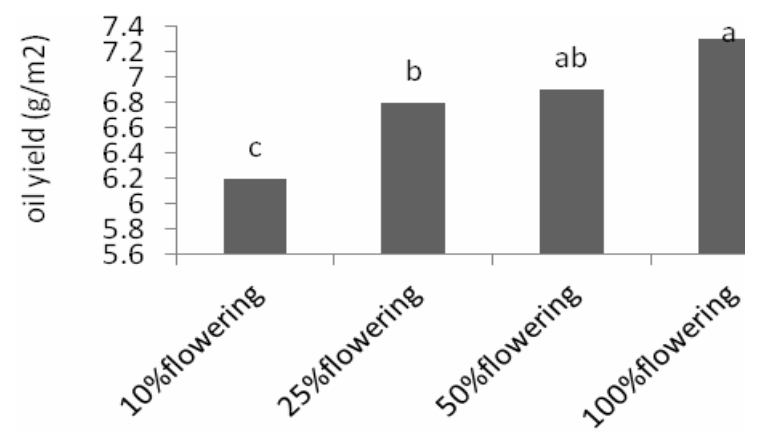

Fig.4. Effect harvest time on oil yield

\section{Leaf Iron content}

Results showed that Fe content was significantly affected by different concentrations of iron fertilizer (Fig. 5) and also harvesting time (Fig. 6). However, interaction between treatments had no significant effect on this trait. Means comparison showed that maximum of $\mathrm{Fe}$ content in leaves was obtained by utilization of iron fertilizer at $6 \mathrm{ml} / \mathrm{l}$ concentration. Our result are in agreement with the results of previous works such as iron foliar application on Chamomile (Matricaria chamomilla L.) reported by Heidari et al., 2011. Fe content was the highest when harvesting was done at $50 \%$ of flowering stage. A possible reason for iron content decrease while harvesting at $100 \%$ of flowering stage may be due to the low concentration of this element, as it enter the molecules structure.

\section{Conclusion}

The purpose of this research was to find the best time for harvest and test the reaction of Dracocephalum moldavica L. to iron foliar application. The results showed that application of iron is very useful. Growth parameters such as plant height, branch numbers, fresh and dry weights, essential oil content and leaf Iron content increased with foliar fertilization. The

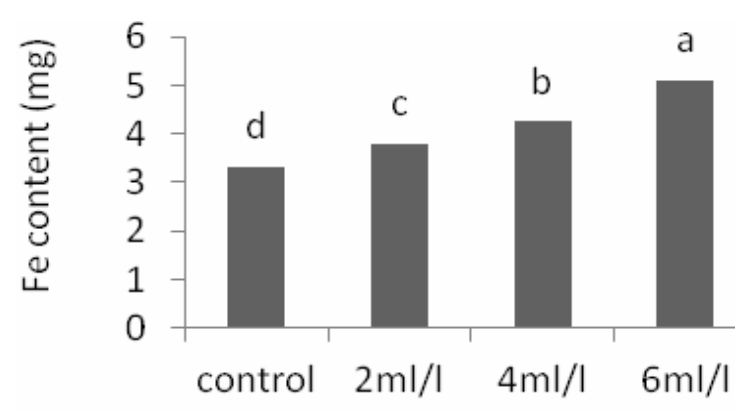

Fig.5. Effect iron application on Fe content 
508

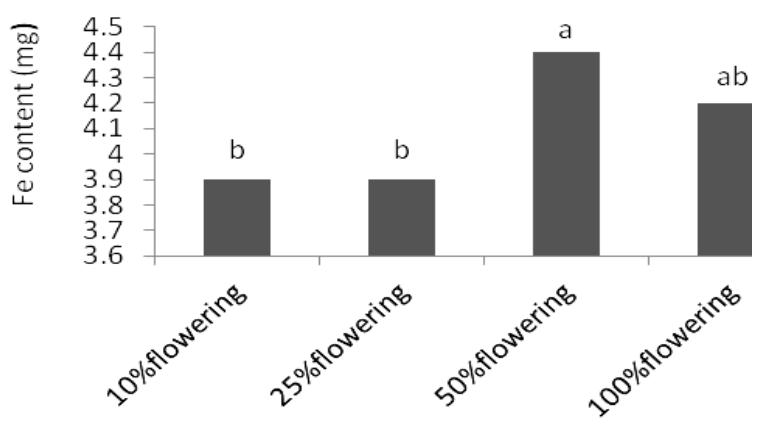

Fig.6. Effect harvest time on Fe content

best harvest time for Dracocephalum moldavica L. was at $100 \%$ of flowering and $6 \mathrm{ml} / \mathrm{l}$ of iron application showed the best results in all characters measured.

\section{References}

Baratta MT, Dorman HJ, Deans SG, Figueiredo AC, Barroso JG, Ruberto $G$ (1998). Antimicrobial and antioxidant properties of some commercial essential oils. J Flav Frag 13(4):235-244.

Brittenham GM (1994). New advances in iron metabolism, iron deficiency and iron overload. Curr Opin Hematol 1(2):101106.

Dastmalchi K, Dorman HG, Laakso I, Hiltunen R (2007a). Chemical compsition and in vitro antioxidant evaluation of a water soluble Moldavian balm (Dracocephalum moldavica L.) extract. J Extr Food Sci Technol 40(2):239-248.

Dastmalchi K, Dorman HG, Laakso I, Hiltunen R (2007b). Chemical composition and antioxidative activity of Moldavian balm (Dracocephalum moldavica L.). J Extr Food Sci Technol 40(9):1655-1663.

Galambosi B, Galambosi ZS, Perrala R, Reppcak M (2002). Yield and quality of selected herb cultivars in Finland. J Acta Hort 576:139-149.

Heidari M, Sarani S (2011). Growth, biochemical components and ion content of chamomile (Matricaria chamomilla L.) under salinity stress and iron deficiency. J Saudi Soci Agri Sci 11(1):3742.

Heidari N, Pouryousef M, Tavakkoli A, Saba J (2011). Effect of drought stress and harvesting date on yield and essential oil production of anise (Pimpinella anisum L.). Iran J Med Aroma Plants 28(1):121-130.

Hopkins WG, Huner NPA (2004). Introduction to plant physiology. John Willy and Sons, Inc. New York, USA. p. 560.

Khoshgoftarmanesh A (1386). Basics of plant nutrition. Esfahan University Publications, Iran. p.485.

Marotti M, Dellacecca V, Piccaglia R, Glovanelli E (1993). Agronomic and chemical evaluation of three varieaties of Foenieulum valgare. J Acta Hort 331:63-69.

Maurya KR (1990). Effect of micronutrients on yield and essential oil content of coriander (Coriandrum sativum L.). J Indian Perfum 34(4):263-265.
Najafi MA, Ghasemian, Gajanii A (2007). The protective effects of Dracocephalum moldavica L. extract of Moldivian balm on infarction size in ischemic rat hearts. Proceedings of the Third Conference on Medicinal Plants, Shahed University, Tehran:24-25 p. 488.

Pande P, Anwar M, Chand S, Yadav VK, Patra DD (2007). Optimal level of iron and zinc in relation to its influence on herb yield and production of essential oil in menthol mint. J Commun Soil Sci Plant Anal 38:561-578.

Pol KM, Mmkhear DG, Awari VR (2003). Physiological studies on influence spray of growth hormones and micronutrients on growth yield of on Withania somniferous L. J Ann Plant Physio 17:45-49.

Rahbarian P, Afshar-Manesh GHR, Shirzadii MH (2009). Effects of water deficit and manure on above ground dry matter and essential oil Moldivian balm (Dracocephalum moldavica L.) on Jiroft region. J Agri Sci, Islamic Azad University of Tabriz 12:55-64. (In Persian with English abstract).

Safikhani F, Heydarye Sharifabadi H, Syadat A, Sharifiashorabadi A, Syednedjad M, Abbaszadeh B (2007). The effect of drought on yield and morphologic characteristics of Dracocephalum moldavica L. Irani J Med Aroma Plants 23(2):183-194.

Said-Al Ahi, HAH, Mahmud AA (2010). Effect of zinc and/or iron foliar application on growth and essential oil of sweet basil (Ocimum basilicum L.) under salt stress. Ozean J Appl Sci 3(1):97-101.

Singh AL, Dayal BD (1992). Foliar application of iron for recovering groundnut plants from lime-induced iron deficiency chlorosis and accompanying losses in yields. J Plant Nutr 15(9):1421-1433.

Takkar PN, Nayyar VK (1979). Iron deficiency affects rice yield in Punjab. Indian Farming 29:9-12.

Venskutonis PR, Dapkevicius A, Baranuauskiene M (1995). Flavour composition of some lemon-like aroma herbs from Lithuania. J Dev Food Sci 37(1):833-847.

ZafarHaider S (2011). Effect of different harvesting time on growth, yield and quality of Thyme (Thymus serpyllum L.) under theagro-climatic condition of Doonvalley, Urtarakhand. J Chem Pharm Res 3(6):982-986.

Zareie S, Golkar P, Ghasem MN (2011). Effect of nitrogen and iron fertilizers on seed yield and yield components of safflower genotypes. African J Agr Res 6(16):3924-3929.

Zehtab-Salmasi S, Heidari F, Alyari H (2008). J Plant Sci Res 1:24-28.

Zehtab-Salmasi S, Behrouznajhad S, Ghassemi-Golezani K (2012). Effects of foliar application of $\mathrm{Fe}$ and $\mathrm{Zn}$ on seed yield and mucilage content of Psyllium at different stages of maturity, Thailand. Int Conf Envi Agric Food Sci (ICEAFS'2012) 1(1):24-26. 